\title{
Impact of land convection on temperature diurnal variation in the tropical lower stratosphere inferred from COSMIC GPS radio occultations
}

\author{
S. M. Khaykin, J.-P. Pommereau, and A. Hauchecorne \\ LATMOS, CNRS-Université de Versailles St Quentin, UMR8190, Guyancourt, France \\ Correspondence to: S. Khaykin (sergey.khaykin@latmos.ipsl.fr) \\ Received: 22 October 2012 - Published in Atmos. Chem. Phys. Discuss.: 2 January 2013 \\ Revised: 8 May 2013 - Accepted: 3 June 2013 - Published: 5 July 2013
}

\begin{abstract}
Following recent studies evidencing the influence of deep convection on the chemical composition and thermal structure of the tropical lower stratosphere, we explore its impact on the temperature diurnal variation in the upper troposphere and lower stratosphere using the high-resolution COSMIC GPS radio-occultation temperature measurements spanning from 2006 through 2011. The temperature in the lowermost stratosphere over land during summer displays a marked diurnal cycle characterized by an afternoon cooling. This diurnal cycle is shown collocated with most intense land convective areas observed by the Tropical Rainfall Measurement Mission (TRMM) precipitation radar and in phase with the maximum overshooting occurrence frequency in late afternoon. Two processes potentially responsible for that are identified: (i) non-migrating tides, whose physical nature is internal gravity waves, and (ii) local cross-tropopause mass transport of adiabatically cooled air by overshooting turrets. Although both processes can contribute, only the lofting of adiabatically cooled air is well captured by models, making it difficult to characterize the contribution of non-migrating tides. The impact of deep convection on the temperature diurnal cycle is found larger in the southern tropics, suggesting more vigorous convection over clean rain forest continents than desert areas and polluted continents in the northern tropics.
\end{abstract}

\section{Introduction}

The tropical tropopause layer (TTL) has long been recognized as the stratospheric "kitchen", setting the boundary conditions for tropospheric tracers entering the stratosphere. However, the potential impact of the troposphereto-stratosphere transport (TST) is highly dependent on the timescale of the processes involved. Indeed, still debated is the global contribution of fast overshooting convective updrafts on a timescale of hours, compared to the slow ascent by radiative heating of the layer above the level of neutral buoyancy (LNB) on a timescale of months (Sherwood and Dessler, 2000, Gettelman et al. 2002; Corti et al. 2005; Fueglistaler et al. 2009). The occurrence of convective overshoots reaching $20 \mathrm{~km}$ with local upward velocities of up to $50-60 \mathrm{~m} \mathrm{~s}^{-1}$ has long been known (e.g. Vonnegut and Moore, 1958; Burnham, 1970; Roach and James, 1972; Cornford and Spavins, 1973; Fujita, 1992; Danielsen, 1982, 1993). Whereas the existence of cross-tropopause transport by deep overshooting is generally accepted, its role in TST had not been assessed until recently since major attention in this context has been paid to the region of the warm pool in the west Pacific instead, where the vast majority of field observations has been carried out. This region was characterized by large-scale slow ascent and minimum outgoing longwave radiation (OLR) used as a proxy for deep convection. However as demonstrated by Alcala and Dessler (2002) from the observations of the precipitation radar (PR) of the Tropical Rainfall Measurement Mission (TRMM), OLR is not a good indicator of cloud penetration into the stratosphere. Indeed, in contrast, the TRMM PR indicates higher and more frequent "overshooting precipitation features" (OPFs) above 
the tropopause over Africa, South America and the Indonesian islands than above oceans (Liu and Zipser, 2005, hereinafter LZ05). Furthermore, the diurnal variation of OPFs displays a marked maximum in the late afternoon over land as opposed to maritime convection, which shows very little diurnal change.

A considerable amount of observational evidence for cross-tropopause mass transport through convective overshooting has been made available by recent field campaigns in South America, Australia and Africa, revealing penetration of tropospheric air and ice crystals up to $19-20 \mathrm{~km}$ over land convective systems (Nielsen et al., 2007; Corti et al., 2008; Khaykin et al., 2009; de Reus et al., 2009; Schiller et al., 2009). Such convective updrafts of adiabatically cooled air and ice crystals across the tropopause are well captured by mesoscale cloud resolving models (Chaboureau et al., 2007; Jensen et al., 2007; Grosvenor et al., 2007; Chemel et al., 2009; Liu et al., 2010), but, because of their non-hydrostatic nature, they are missed by global meteorological and climate models. The relative importance of the contribution of such continental convective updrafts compared to their oceanic counterparts is suggested by the higher concentration of tropospheric trace gases in the TTL above continents reported by space-borne $\mathrm{N}_{2} \mathrm{O}, \mathrm{CH}_{4}$ and $\mathrm{CO}$ profiles measurements (Ricaud et al., 2007, 2009). Another indication of the importance of these is provided by the fast cleansing of stratospheric aerosols up to $20-21 \mathrm{~km}$ altitude resulting from the injection of clean tropospheric air during the Southern Hemisphere convective season observed by the CALIPSO lidar (Vernier et al., 2009, 2011).

The influence of deep convection on the thermal structure of the upper troposphere/lower stratosphere (UTLS) has been studied by many authors. Gettelman and Birner (2007) characterized the regional convective temperature signal as warming of the upper troposphere due to latent heat release and cooling at TTL levels. Holloway and Neelen (2007) described the cooling at TTL levels as a natural response to latent heating, producing hydrostatic pressure gradients and forcing ascent and adiabatic cooling. A large-scale cold anomaly near the tropopause is commonly associated with convectively coupled equatorial waves (e.g. Randel and $\mathrm{Wu}$, 2003; Sherwood et al., 2003; Norton, 2006; Kiladis et al., 2009) or the Madden-Julian oscillation (Kiladis et al., 2005; Zeng et al., 2012). There is a considerable amount of observational evidence of local cooling of the lower stratosphere over land convective systems, ranging from $2 \mathrm{~K}$ to 10 K (e.g. Johnson and Kriete, 1982; Danielsen, 1993; Sherwood and Dessler, 2003; Pommereau and Held, 2007; Cairo et al., 2010; Biondi et al., 2012). However the contributions of various processes to the TTL thermal structure are still unclear.

The question addressed by the present study is how deep convection could influence the thermal structure of the TTL and the LS on a diurnal scale. The diurnal oscillations in the atmosphere are termed solar atmospheric tides, which represent global-scale waves with periods that are harmonics of the solar day (Chapman and Lindzen, 1970). The tides are classified as migrating and non-migrating types, both generated in the tropical troposphere and propagating as internal gravity waves transporting energy up and away from their source region. The amplitude of the vertically propagating oscillations increases with altitude. The migrating tides, which propagate westward with the apparent motion of the sun, are primarily excited by the zonally symmetric absorption of solar radiation by tropospheric moisture and stratospheric ozone. The non-migrating tides (nonsun-synchronous modes, which can propagate either westward or eastward or stay stationary) are generated by zonally asymmetric thermal forcing such as planetary boundary layer heat flux, latent heat release in the tropical troposphere or non-linear interactions between tides and other propagating waves (Teitelbaum and Vial, 1991; Williams and Avery, 1996; Hagan and Forbes, 2002; Lieberman et al, 2004; Oberrheide et al., 2002). Migrating tides are mainly upper atmospheric features, where for example the amplitude of the diurnal temperature cycle exceeds $20 \mathrm{~K}$ at $115 \mathrm{~km}$ (Zhang et al., 2006). They are well understood and comprehensively documented in many observational and theoretical studies, and well represented in global ECMWF and NCEP meteorological models (Pirscher et al., 2010). In contrast, the nonmigrating tides, particularly in the UTLS region, are poorly documented and their sources and behaviors are still not well known. Indeed, the available ground-based observations do not allow separation of migrating and non-migrating tides (Pirscher et al., 2010, and references therein). A significant progress in tide studies has been achieved thanks to the GPS radio-occultation (RO) technique utilized by the CHAMP (CHAllenging Minisatellite Payload) mission and the subsequent, more elaborated COSMIC mission, providing highresolution temperature profiles in the UTLS. Several studies of the temperature diurnal cycle associated with migrating tide in the stratosphere at low and mid-latitudes are available (e.g. Zeng et al., 2008; Xie et al., 2010; Pircher et al., 2010) but noticeably never distinguishing between continents and oceans.

Here we investigate the temperature diurnal cycle in the tropical UTLS and its possible connection with deep convection, using a 6 yr 3-dimensional temperature data set provided by the COSMIC GPS RO mission. The geographical distribution of the temperature diurnal cycle is characterized and compared to that of deep convection provided by the TRMM PR overshooting precipitation features (OPFs). Since many spectral analyses of atmospheric tides at the global scale are already available in the literature, they will not be repeated here, and the study will focus on the spatiotemporal distribution of the temperature diurnal cycle. The paper is organized as follows. Section 2 provides a description of the COSMIC RO data set and the methodology used. The results are described in Sect. 3, followed by a discussion in Sect. 4 and a summary of conclusions in Sect. 5. 


\section{Data and methodology}

The data used are the temperature profiles derived from the six micro-satellites of the FORMOSAT-3/COSMIC mission (Formosa Satellite Mission-3/Constellation Observing System for Meteorology, Ionosphere and Climate) (Anthes et al., 2008) launched in April 2006 jointly by NASA and Taiwan's National Space Organization. The occultation system comprises six low-orbiting satellites evenly distributed in space providing a spatial coverage of $1500-2500$ occultations per day. GPS RO measurements are intrinsically calibrated and stable in the long term (Steiner et al., 2009). They feature best quality in the upper troposphere and lower stratosphere between 10 and $25 \mathrm{~km}$ altitude (Scherllin-Pirscher et al., 2011b), high accuracy and precision $(<1 \mathrm{~K}$ for temperature), as well as high vertical resolution varying from $0.2 \mathrm{~km}$ in the troposphere to $1.4 \mathrm{~km}$ in the stratosphere (Kursinski et al., 2000; Anthes et al., 2008). Insensitive to clouds and precipitation, the GPS RO technique provides all-weather observations with global coverage and diurnal sampling capability.

The primary product of the GPS RO technique is the bending angle as a function of tangent height, from which the profile of refractivity can be retrieved from the top of the atmosphere down to the troposphere using the so-called onionpeeling approach. The temperature and humidity profiles can then be further retrieved from the refractivity (Rocken et al., 1997). Extensive validation of the RO measurements against other observations and models as well as error estimations have been carried out by several authors (e.g., Kuo et al., 2004; Schreiner et al., 2007, Scherllin-Pirscher et al., 2011a, b). The total climatological error in dry temperature estimated by Scherllin-Pirscher et al. (2011a) amounts to $0.15 \mathrm{~K}$ between $10 \mathrm{~km}$ and $20 \mathrm{~km}$ altitude and increases exponentially to about $0.4 \mathrm{~K}$ at $35 \mathrm{~km}$. The uncertainties may be higher for the measurements in the strong convective systems, since the model used for temperature retrieval may not properly account for the vertical moisture transport.

The data used here are the COSMIC GPS RO level 2 data products called wetPrf (wet profile), which is an interpolated product of $100 \mathrm{~m}$ vertical resolution obtained by the onedimensional variational (1DVar) technique, where the refractivity is weighted in such a way that the resulting temperature is the same as the dry temperature in the regions of insignificant water content (Biondi et al., 2011). The data include latitude and longitude of the tangent point, pressure, temperature, water vapor pressure, refractivity and altitude of the perigee above sea level. The data in NetCDF format are available from the CDACC (COSMIC Data Analysis and Archive Center) website hosted by the University Corporation for Atmospheric Research (UCAR).

The COSMIC data used in this study span from 2006 through 2011, whereas the analysis was restricted to solstice months, i.e., austral summer (DJF) and boreal summer (JJA) at low latitudes between $25^{\circ} \mathrm{S}$ and $25^{\circ} \mathrm{N}$. The interpolated profiles are indexed with respect to the tangent point lati- tude and longitude at $17 \mathrm{~km}$ altitude, the mean altitude of the tropical cold point tropopause (CPT). The diurnal variation of temperature is examined by looking at its anomaly compared to the daily mean profile within the $10-35 \mathrm{~km}$ altitude range.

\section{Observational results}

The temperature diurnal cycle in the tropics is first examined using the zonal-mean temperature anomaly between 10 and $35 \mathrm{~km}$ altitude in the southern and northern tropics during DJF and JJA, respectively, as well as the latitude-height distribution of the temperature diurnal amplitude between $25^{\circ} \mathrm{S}$ and $25^{\circ} \mathrm{N}$. The influence of continents on the diurnal cycle is then characterized by plotting the difference between land and oceanic areas. Finally, the impact of convective and nonconvective regions on the phase and amplitude of the temperature diurnal cycle in the mid- and lower stratosphere and the differences between the Northern $(\mathrm{NH})$ and Southern $(\mathrm{SH})$ hemispheres are explored using Hovmoller plots of the diurnal cycle in the austral and boreal summers.

\subsection{Zonal-mean profile of temperature diurnal cycle}

Figure 1 shows the altitude distribution of zonally averaged diurnal temperature anomalies in the northern $\left(0-25^{\circ} \mathrm{N}\right)$ and southern $\left(0-25^{\circ} \mathrm{S}\right)$ tropical belts in JJA and DJF. The temperature variations of largest amplitude are observed around $30 \mathrm{~km}$, gradually decreasing below. Both $\mathrm{NH}$ and $\mathrm{SH}$ tropics show a downward progression of diurnal temperature anomalies of $24 \mathrm{~h}$ period, shifted downward in the summer compared to the winter in both hemispheres. A notable enhancement in amplitude is shown in summer in both hemispheres around $17-20 \mathrm{~km}$, which is more prominent in the south than in the north. A late-afternoon cooling and a nighttime-earlymorning warming characterize the temperature cycle in this region. A further amplitude enhancement is observed in the summer in the upper troposphere below $15 \mathrm{~km}$, displaying a minimum between 03:00 and 07:00 LT and a maximum in the early evening between 18:00 and 22:00.

The downward phase propagation of the temperature anomalies in the mid-stratosphere is the well-known signature of migrating tides already reported by previous studies exploiting COSMIC data and showing an increase of amplitude with height and a local maximum in winter (Pirscher et al., 2010; Xie et al., 2010). The temperature diurnal cycle in the lower stratosphere in local summer, of larger amplitude in the $\mathrm{SH}$, is out of phase with the upper-tropospheric diurnal cycle, which displays a late-afternoon warming due to latent heat release during the development phase of convection followed by a nighttime cloud radiative cooling.

Figure 2 displays the altitude/latitude distribution of the diurnal temperature cycle amplitude in DJF and JJA within the full $25^{\circ} \mathrm{N}-25^{\circ} \mathrm{S}$ tropical belt. The elevated amplitudes 

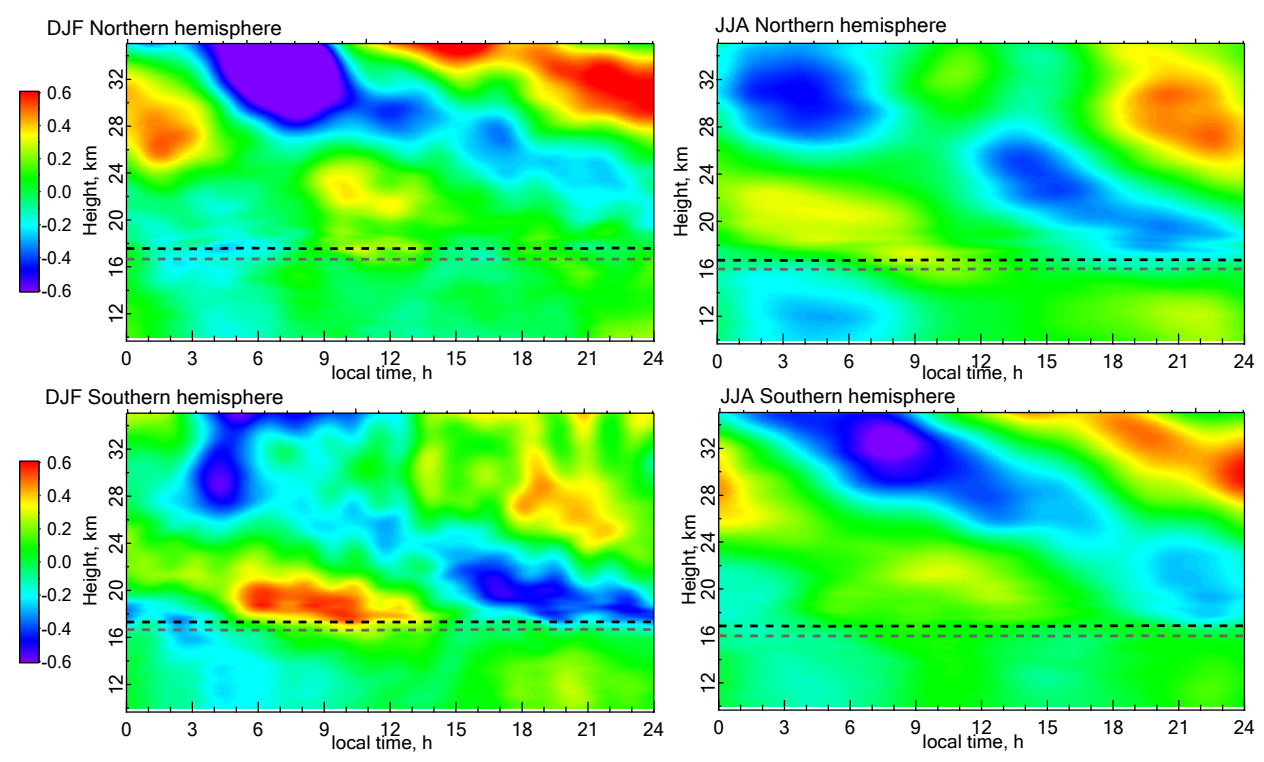

Fig. 1. Zonally averaged temperature diurnal anomalies in the northern (top) and southern (bottom) tropical belts $\left(25^{\circ} \mathrm{N}-0^{\circ}\right.$ and $\left.0-25^{\circ} \mathrm{S}\right)$ in DJF (left) and JJA (right). Black and gray dashed lines denote mean CPT and LRT levels respectively.
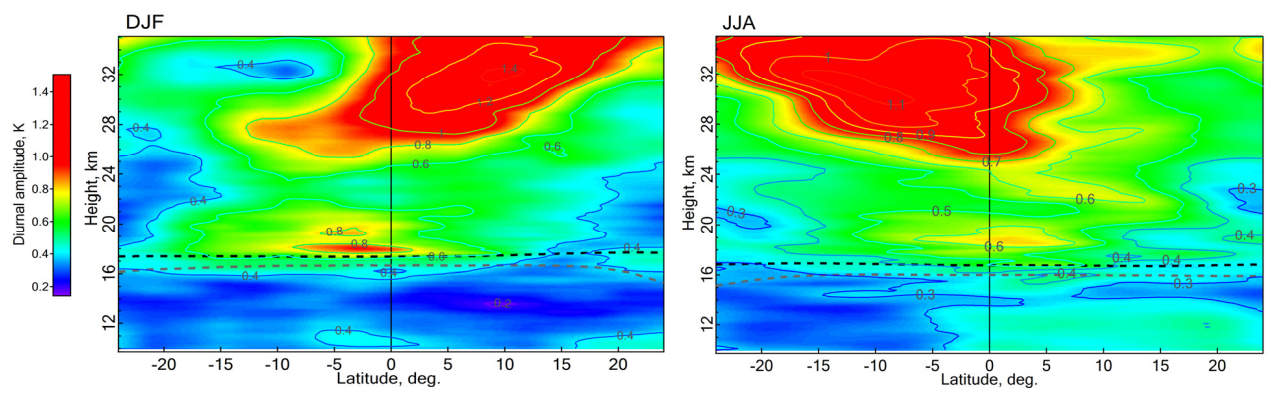

Fig. 2. Zonal-mean temperature diurnal amplitude between $25^{\circ} \mathrm{N}$ and $25^{\circ} \mathrm{S}$ in DJF (left) and JJA (right).

above $26 \mathrm{~km}$ are the manifestation of migrating tide. The vertical structure, the amplitude and the winter maximum of the tide fully agree with those derived from the CHAMP (Zeng et al., 2008) and COSMIC data (Pirscher et al., 2010; Xie et al., 2010), and the simulations of the Canadian Middle Atmosphere Model (McLandress, 2002). According to these authors, the seasonal variation is attributed to an interference of latitudinal symmetric and anti-symmetric vertically propagating modes of waves with different vertical wavelengths. The NH summer shows an additional diurnal cycle enhancement around $23-25 \mathrm{~km}$, not seen in the SH summer, which is discussed in Sect. 3.4.

A lower thin layer of $0.8 \mathrm{~K}$ amplitude is observed in the lowermost stratosphere within $10^{\circ} \mathrm{S}-2^{\circ} \mathrm{N}$ between the CPT and $20 \mathrm{~km}$ in DJF, and of $0.6 \mathrm{~K}$ within $2^{\circ} \mathrm{S}-5^{\circ} \mathrm{N}$ in JJA but around $19-20 \mathrm{~km}$ only. The local maximum in amplitude in the season when the migrating tide is weakest suggests an additional mechanism other than the migrating tide. Another noticeable feature is the larger amplitude and wider latitude extension of the diurnal cycle in the $\mathrm{NH}$ upper troposphere compared to the $\mathrm{SH}$.

Overall, the vertical structure of the temperature diurnal variation exhibits three amplitude enhancements: (i) a broad one above $26 \mathrm{~km}$, maximizing in the winter; (ii) a thin local maximum between 17 and $20 \mathrm{~km}$ in the summer only of larger amplitude in the south; and (iii) an upper tropospheric enhancement in the summer hemisphere of larger amplitude in the $\mathrm{NH}$. Whereas the migrating tide origin of the enhanced amplitude above $26 \mathrm{~km}$ and that of the latent heat release and radiative cooling of the troposphere are well understood, the cause of the sharp local maximum in the lower stratosphere during the convective summer season is less clear. The question is whether this cycle is uniform in longitude or dependent on the land-ocean distribution. 

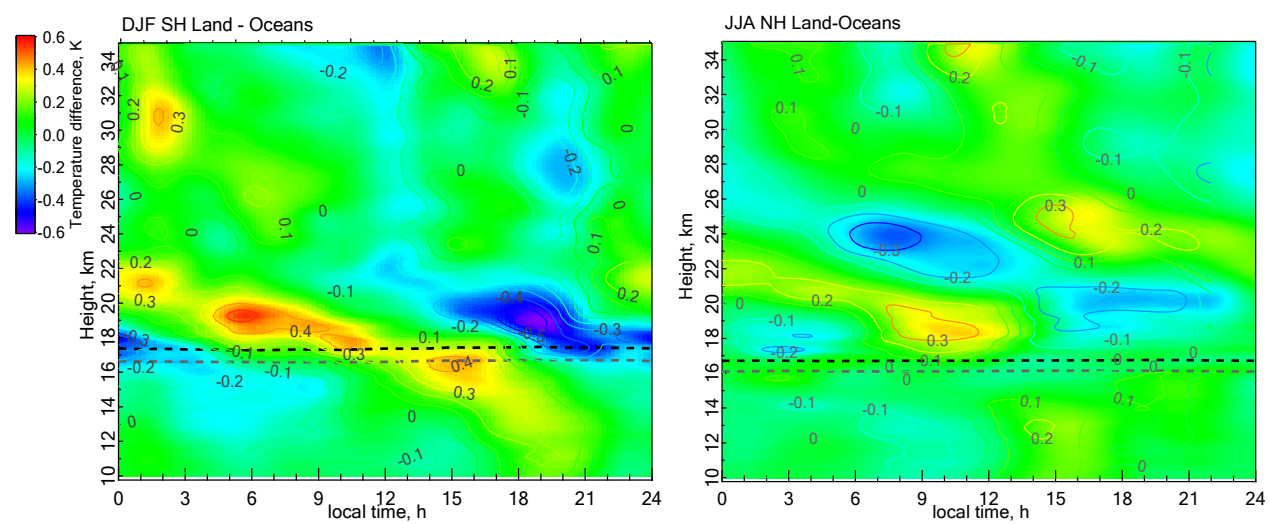

Fig. 3. Difference between diurnal temperature anomalies above land and oceans in DJF in the SH (left) and in JJA in the NH (right), where land and oceanic domains are defined as areas of highest and lowest TRMM PR OPF occurrence frequency (Liu and Zipzer, 2005). Black and gray dashed lines denote CPT and LRT levels above land areas.

\subsection{Difference between temperature diurnal cycle above continents and oceans}

An answer to this question is provided by the difference between the temperature diurnal variations over land and oceans in the SH and NH summers shown in Fig. 3. In the mid-stratosphere the signatures of the zonally invariant migrating tides are removed, indicating that these are independent of the geographical distribution of continents in both hemispheres. In the SH tropical summer (left of Fig. 3) the only altitude region where the difference is significant is the UTLS. The afternoon tropospheric warming between 13:00 and 18:00 and the cooling between 03:00 and 10:00 are larger over land. The afternoon LS cooling between 15:00 and 20:00 at 17-21 km, drifting downward during the night, is on average $0.6 \mathrm{~K}$ larger over continents than over oceans. The picture in JJA in the NH is somewhat different. The UTLS afternoon cooling is of smaller amplitude in the NH not displaying downward propagation, whereas the late-night warming is shifted to the mid-morning. In addition, the $\mathrm{NH}$ JJA plot exhibits a diurnal cycle in the mid-stratosphere at $23-26 \mathrm{~km}$, which is absent in SH DJF.

\subsection{Zonal variation of temperature diurnal cycle in the UTLS}

For better understanding of the land/ocean differences and their possible origin, Fig. 4 shows a Hovmoller geodiurnal diagram of the diurnal temperature anomaly within a $1.5 \mathrm{~km}$ layer above the local CPT in the SH and NH summer tropical belts. The geodiurnal temperature pattern in the $\mathrm{SH}$ in DJF on the left of Fig. 4 shows systematic afternoon cooling followed by nighttime warming over central Africa and Amazonia and, of lesser amplitude, over northern AustraliaIndonesian islands and the west Pacific. Remarkably, the continental cold and warm anomalies extend westward to the adjacent oceanic areas.
The geodiurnal temperature pattern in NH JJA is significantly different from that of SH DJF, displaying three diurnal cycle regimes: (i) a land-convective-type cycle over west Africa similar to that observed above SH continents in DJF and over northern South America but of smaller amplitude, (ii) an oceanic-type cycle with a nighttime warming and a morning cooling, and (iii) a semi-diurnal cycle with eastward-propagating warm and cold anomalies above South Asia and the bay of Bengal during the monsoon season. Geodiurnal patterns at higher levels show that the latter cycle is limited to $17-19 \mathrm{~km}$ altitude. Overall, the Hovmoller diagrams in Fig. 4 indicate that the diurnal cycles of largest amplitude in the lower stratosphere are observed above land areas during the summer convective season and of significantly larger amplitude in the Southern Hemisphere. But a still-open question is which process is responsible.

Figure 5 displays the geographical distribution of the temperature difference in a $1 \mathrm{~km}$-thick layer above the local CPT between the late afternoon (18:00 \pm 02:00) and the morning (10:00 \pm 02:00), the periods of maximum and minimum convective activity over land (LZ05). The COSMIC profiles are binned into $5^{\circ} \times 5^{\circ}$ boxes, each comprising over 300 profiles on average. Also shown in Fig. 5 is the geographical distribution of frequency of occurrence of TRMM PR overshooting precipitation features above $14 \mathrm{~km}$ adopted from LZ05. The coincidence between the location of late-afternoon cooling and overshooting convection above continental areas is nearly perfect in DJF. The largest OPF frequency and the largest afternoon cooling are observed over Africa and South America. Although more dispersed and of smaller amplitude, collocated cooling features and OPFs are also observed over Indonesian islands and northern Australia. In JJA the afternoon cooling features are seen over convective areas of central and west Africa, northern South America, Indonesian islands and the west Pacific, but absent over the convective Central America and India. In summary, significant 

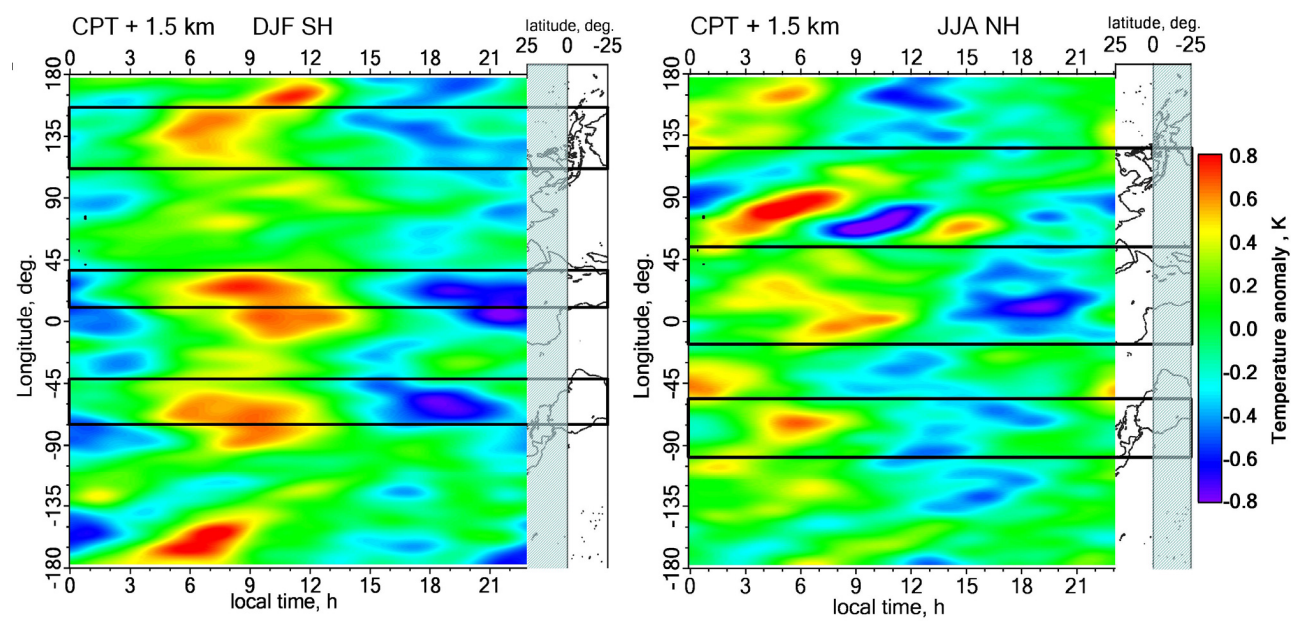

Fig. 4. Geodiurnal variation of temperature anomaly between $0-25^{\circ} \mathrm{S}$ and $0-25^{\circ} \mathrm{N}$ during the local summer in DJF (left) and JJA (right) in a $1.5 \mathrm{~km}$-thick layer above the local CPT. Land areas are enclosed in black rectangles corresponding to the continent limits shown on the maps on the right of the diagrams.
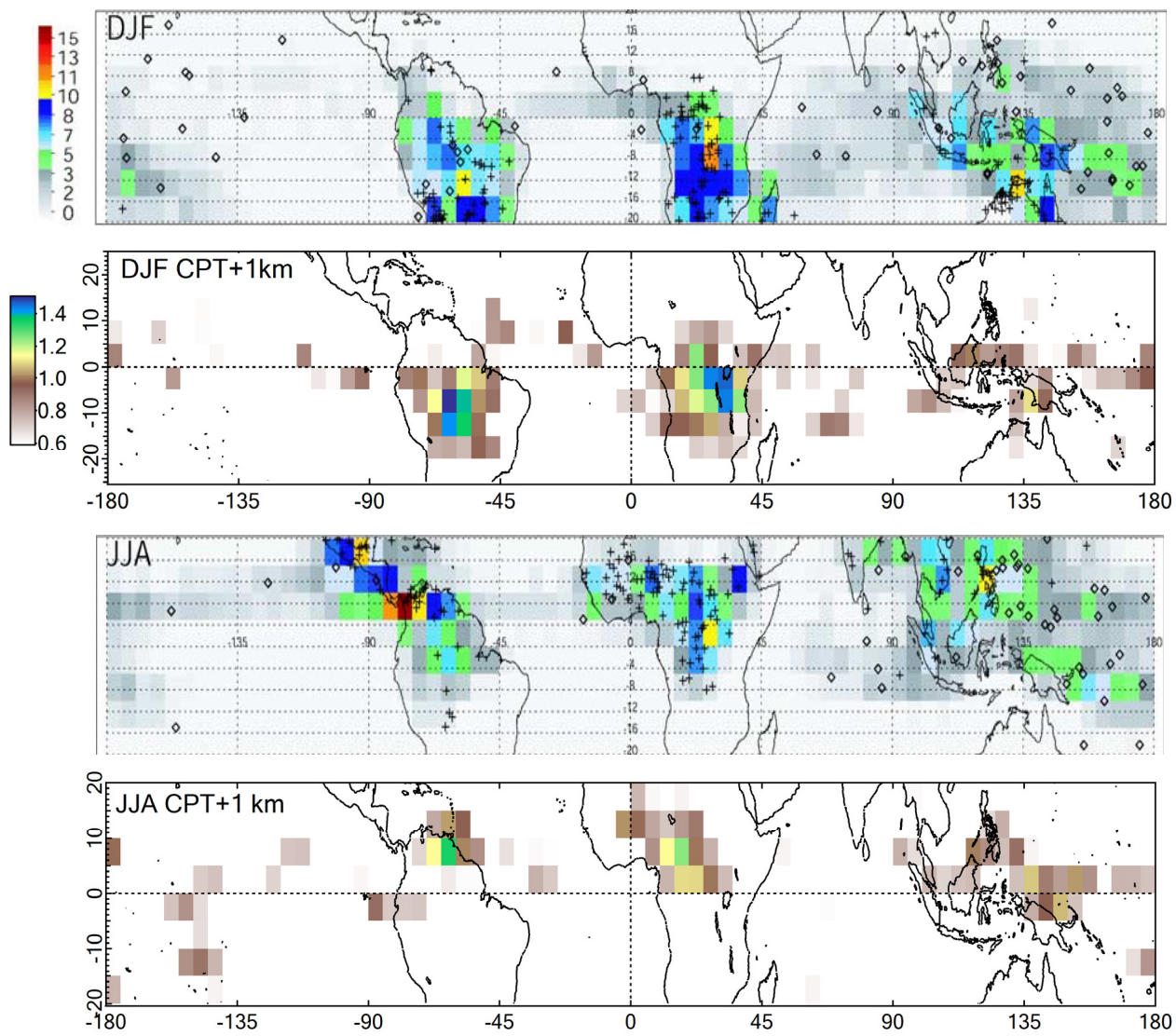

Fig. 5. Comparison between geographical locations of late-afternoon cooling in the $1 \mathrm{~km}$-thick layer above the local cold point tropopause (2nd and 4th panels) and TRMM OPF density number above $14 \mathrm{~km}$ (1st and 3rd panels, adapted from LZ05). Top panels: DJF; bottom: JJA. The OPF frequency of occurrence is in units per thousand in each bin divided by the TRMM 3A25 total pixel number for removing the sampling bias. The color scale of the cooling is the value of the mean difference between late afternoon (18:00 $\pm 02: 00)$ and morning $(10: 00 \pm 02: 00)$ temperatures. 

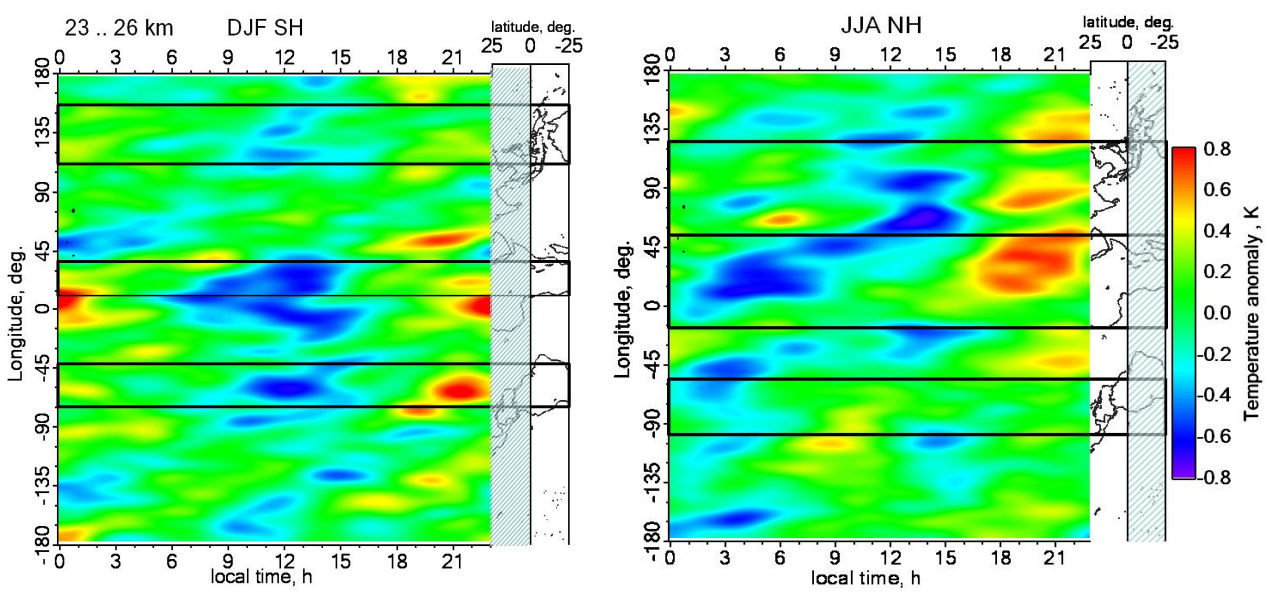

Fig. 6. Geodiurnal variation of temperature anomaly between $0-25^{\circ} \mathrm{S}$ and $0-25^{\circ} \mathrm{N}$ during the local summer in DJF (left) and JJA (right) in a layer between 23 and $26 \mathrm{~km}$ altitude. Land areas are enclosed by black rectangles corresponding to the continent limits shown on the maps on the right of the diagrams.

afternoon cooling in the lower stratosphere is confined to the land convective areas and larger over southern continents compared to northern ones.

\subsection{Temperature diurnal cycle in the mid-stratosphere}

The difference between land and ocean diurnal temperature anomalies in Fig. 3 exhibits a diurnal cycle, characteristic of an early-morning cooling and an afternoon warming in the mid-stratosphere around $23-26 \mathrm{~km}$ during the NH summer, which is absent in the SH summer. The geodiurnal temperature variations at this level are shown in Fig. 6. The $\mathrm{SH}$ summer displays a late-evening temperature maximum and a noontime minimum over Africa, the east Atlantic and South America, implying a warming during late afternoon, but little diurnal change in the Pacific and the Indian Ocean. The pattern is different in the northern tropics during JJA, showing a strong daytime warming of $1.1 \mathrm{~K}$ peak-to-peak amplitude over the Sahara and Saudi Arabian desert regions and, though of lesser amplitude, over the South Asian monsoon region. The large amplitude and longitudinal extension of the diurnal cycle over deserts strongly weight the zonal-mean landocean difference in the NH shown in Fig. 3, which is not the case for SH tropics of smaller desert areas.

The daytime warming of the mid-stratosphere over deserts is attributed to long- and shortwave radiation absorption by ozone at the altitude of its maximum concentration. It is due to the large OLR diurnal increase from $290 \mathrm{~W} \mathrm{~m}^{-2}$ in the early morning to $370 \mathrm{~W} \mathrm{~m}^{-2}$ in the afternoon after the solar heating of the desert surface (Schmetz and Liu, 1988; Smith and Rutan, 2003) and the noontime maximum of shortwave solar light reflected by 0.31 albedo at $630 \mathrm{~nm}$ (Harrison et al., 1990; Minnis and Young, 2002). The observed $1.1 \mathrm{~K}$ peakto-peak amplitude of the daytime heating around $23-26 \mathrm{~km}$ is consistent with the radiative model calculations of Gettelman et al. (2004).

Of similar radiative origin, but of lesser amplitude and shifted in time, are the mid-stratosphere diurnal cycles over Africa and South America during the SH summer and India during the monsoon season. The morning cooling over these areas coincides with the OLR drop during the development phase of convection and the fast afternoon heating, and the period of maximum solar light reflection of cloud anvils. The smaller amplitude of the diurnal cycle over oceanic convective regions is consistent with the little diurnal change of maritime convection.

In summary, the mid-stratosphere temperature diurnal cycle is fully consistent with the radiative heating of the ozone layer by short- and longwave radiation diurnal variations varying with the nature of the surface and the cloud cover.

\section{Discussion}

The COSMIC data analysis reveals a variety of temperature diurnal cycles of different origins in the tropical upper troposphere and stratosphere. Those of the upper stratosphere are dominated by the signature of migrating tide, responsible for the zonally invariant diurnal cycle above $26 \mathrm{~km}$. The diurnal cycle in the upper troposphere originates from the convective latent heat release in the afternoon followed by radiative cooling at night. The mid-stratosphere cycle of maximum amplitude over desert areas is explained by the diurnal modulation of radiative heating at the altitude of the maximum ozone concentration by absorption of short- and longwave radiation, reflected and emitted by the surface. The only remaining open question is the mechanism responsible for the diurnal variation in the lower stratosphere of maximum amplitude over land convective areas. The spatial and temporal 
collocation of the afternoon cooling with the development phase of land convection suggests a process directly linked with the latter.

The colder TTL above convective areas is a well-known feature, reported by many authors quoted in the introduction, but notably with little reference to a possible difference between land and oceans, where convection characteristics are totally different. Although the cooling is generally attributed to convectively coupled equatorial Kelvin and Rossby waves, they cannot result in a diurnal cycle, since their periods exceed $24 \mathrm{~h}$. The same applies to gravity waves of $24 \mathrm{~h}$ period, which are normally non-synchronous to local time (Tsuda et al., 1994). Thus, the only remaining processes which could generate a diurnal cycle over land convection are (i) nonmigrating tides, whose physical nature is internal gravity waves and (ii) local cross-tropopause transport of adiabatically cooled air by overshooting towers.

\subsection{Origin of temperature diurnal cycle in the lower stratosphere}

While the non-migrating tide is well known to be induced by convective latent heat release in the troposphere, its effect is mainly identified at levels above $40 \mathrm{~km}$. Several authors have found a manifestation of non-migrating tides in the lower stratosphere winds (e.g. Tsuda et al., 1994); however, no information regarding the thermal response to these tides has been provided. Alexander and Tsuda (2008) and Zeng et al. (2008) report a local maximum in amplitude of temperature diurnal variation in the tropical lower stratosphere at local and global scales but without explicit information on the responsible process. As can be seen in Fig. 1, the descending warm and cold phase fronts are nearly continuous from the upper stratosphere, where migrating tides are dominant, down to the lowermost stratosphere, where the amplitude of this oscillation is significantly enhanced. This feature can be attributed to an interaction between zonally invariant migrating tide and convectively induced non-migrating tides, confined over land areas. In addition, according to Tsuda et al. (1994) the non-migrating tides are characterized by highorder modes of small vertical scale, rapidly dissipating during their upward propagation in a strong wind shear near the tropopause, which could explain the restriction of temperature response to the lower stratosphere. Another dynamical feature is reflected by the zonal propagation of temperature anomalies seen in the UTLS geodiurnal pattern (Fig. 4), showing an extension of the land diurnal cycle over the adjacent oceans with a small phase shift. A very similar effect was detected in brightness temperature by Yang and Slingo (2001), who tentatively attributed it to gravity waves of varying depth.

Another process involving wave activity above convective systems is the breaking of gravity waves, generated by thunderstorms on top of their overshooting domes (Alexander et al., 1995; Lane et al., 2001, 2003), leading to the forma- tion of "jumping cirrus" reported by Fujita (1992). As shown by Wang (2004) using a three-dimensional non-hydrostatic cloud model, this process leads to an irreversible diabatic transport of tropospheric materials at $8 \mathrm{~m} \mathrm{~s}^{-1}$ vertical velocity up to $3-4 \mathrm{~km}$ above the cloud anvil, that is, at about $17-18 \mathrm{~km}$ altitude in the tropics. However no information is available on the possible impact of such an event on the thermal structure of the lower stratosphere, although it is conceivable that these gravity waves could contribute to the generation of non-migrating tides.

Finally, a very well known and fully understood process resulting in a strong cooling of the lower stratosphere is the lofting of adiabatically cooled air by overshooting turrets, followed by turbulent mixing with warmer stratospheric air, a process suggested and further demonstrated by Danielsen (1982), and confirmed by many other studies quoted in the introduction. Successfully reproduced by nonhydrostatic cloud resolving models (e.g. Chaboureau et al., 2007; Grosvenor et al., 2007; Liu et al., 2010), these updrafts of $35 \mathrm{~m} \mathrm{~s}^{-1}$ to $80 \mathrm{~m} \mathrm{~s}^{-1}$ vertical velocity result in local injection of adiabatically cooled air into the lower stratosphere and a local cooling by e.g. $21 \mathrm{~K}$ at $18.2 \mathrm{~km}$ in the case simulated by Jensen et al. (2007). The turbulent mixing may be enhanced by the gravity wave breaking, which results in a vertical extension of the mixing layer (Lane et al., 2003). The colder and heavier air masses, having been detrained in the LS, then descend, resulting in an adiabatic heating of the layer. Considering the late-afternoon maximum of land convection, such a process could partly explain the vertical structure of convectively driven diurnal variation (Fig. 3). It should be noted, though, that since overshooting events are of small spatial scale (typically $10 \mathrm{~km}$ ) and short duration (10$20 \mathrm{~min}$ ), their impact on the thermal structure of the lower stratosphere at a larger scale will depend on their occurrence frequency. According to Iwasaki et al. (2010), the total number of overshoots penetrating the level of $380 \mathrm{~K}$ above the tropical continents and the warm pool is $7 \times 10^{6}$ per year as estimated from CloudSat radar observations.

An important consideration regarding the adiabatic cooling process is the altitude reached by overshoots, which defines the top altitude of the direct influence of the troposphere, i.e., the top of the TTL. Though the probability of an overshoot reaching a given level decreases exponentially with height (LZ05), the amplitude of the cooling increases with the altitude of detrainment. The COSMIC RO temperatures show an average maximum cooling at $19.2 \mathrm{~km}$, i.e., $2 \mathrm{~km}$ above the mean CPT during the SH summer. This altitude is consistent with the observations of geyser-like injections of ice crystals up to the same level and the zonal-mean convective cleansing of the aerosols in the SH lower stratosphere by injection of clean air up to $20 \mathrm{~km}$ (see introduction).

In summary, both non-migrating tides and overshooting updrafts may be responsible for the temperature diurnal cycle above deep convective areas. The fundamental difference 
between them is the nature of the process, energy transfer for the first and mass transfer for the second. Thus, the response to tidal oscillations may occur higher in the stratosphere and distant horizontally from the most active thunderstorm regions, whereas the impact of overshooting would be limited to the maximum altitude of the updrafts around $19-20 \mathrm{~km}$. Currently, the convective overshooting process is adequately reproduced by mesoscale cloud models, whereas model representation of non-migrating tides is still problematic. The investigation of their relative contributions would require synoptic-scale modeling, allowing cross-tropopause convective transport and/or simulation of lower stratospheric temperature response to non-migrating tides.

\subsection{Difference between northern and southern tropics}

An unexpected finding of the COSMIC RO temperature analysis is the larger amplitude of the diurnal cycle over land in the lower stratosphere in the tropical southern summer compared to the northern. Remarkably, this is consistent with the more efficient cleansing of the aerosols reported by Vernier et al. (2011) and the higher concentration of tropospheric trace gases concentrations (Ricaud et al., 2009) in the lower stratosphere in austral summer compared to boreal summer, implying a more vigorous convection in the southern tropics. This conclusion is consistent with that derived by Zipser et al. (2006) and Liu and Zipser (2009) from the TRMM PR observations, indicating higher OPF frequency, that is, more vigorous convection above the Congo basin in central Africa and Amazonia during the austral summer than anywhere in the boreal summer.

\section{Summary}

The six-year COSMIC RO temperature profiles have been used to characterize the temperature diurnal variation in the tropical UTLS and investigate its relationship with land convection. The analysis reveals a signature of the well-known migrating solar tide in the upper stratosphere above $26 \mathrm{~km}$ altitude and specific diurnal cycles at several levels below: between $23-26 \mathrm{~km}$ in the mid-stratosphere; between the cold point tropopause and $20 \mathrm{~km}$; and in the upper troposphere. While the upper-level migrating tide signal is shown to be independent of the geographical distribution of continents, all others are found enhanced above land compared to oceans. The mid-stratosphere diurnal cycle over the Sahara and Saudi Arabian deserts is explained by the radiative heating of the ozone layer modulated by a strong diurnal cycle of longwave radiation and reflected sunlight, specific to these regions.

In the TTL and lowermost stratosphere the temperature diurnal cycle, characterized by an afternoon cooling, is found collocated in space and time with land convective systems developing in the afternoon during the summer as detected by the TRMM precipitation radar. The largest LS temper- ature cycle is observed above Africa, South America and Indonesian islands in austral summer and of lesser amplitude above west Africa and northern South America in boreal summer. The late-afternoon cooling between the tropopause and $20 \mathrm{~km}$ altitude over land is shown unambiguously coupled with land convection, and two mechanisms are invoked. The first is non-migrating tides generated by convective diabatic heating, possibly interacting with migrating tides, and gravity waves. Such process implies energy transfer only. Another mechanism involving in contrast mass transport, well reproduced by the mesoscale models, is the systematic injection and turbulent mixing of adiabatically cooled air by cross-tropopause updrafts. The reality of this hypothesis is strengthened by the many recent observations of ice crystals, tropospheric trace gases and clean air injections into the lower stratosphere, all of them requiring transfer of mass and not of energy only. An alternative way of cross-tropopause mass transport, but of diabatic nature, is gravity wave breaking atop severe thunderstorms, enhancing turbulent mixing and producing "jumping cirrus". Both non-migrating tides and overshoots may contribute to the observed temperature diurnal cycle, although overshoots only are adequately reproduced by models. Quantifying the relative contributions of these processes would require a convection-permitting modeling study over a large domain.

The further information delivered by the COSMIC RO temperatures is the larger impact of convection in the southern tropics compared to the northern, which, together with the similar conclusions for trace gases and clean air injections, would imply more vigorous overshooting over SH land areas.

Acknowledgements. The COSMIC RO data used in this study are those available from the Data Analysis and Archive Center (CDAAC) of the University Corporation for Atmospheric Research (http://cdaac-www.cosmic.ucar.edu/cdaac/). The work was supported by the French Agence Nationale de la Recherche (ANR) Tro-Pico project (http://www.univ-reims.fr/site/autre/tro-pico/) and partly by EU FP7 ARISE project (no. 284387) and Russian MK-2912.2013.5 grant. We thank Geraint Vaughan for valuable suggestions, which helped considerably improve the manuscript.

Edited by: F. Fierli

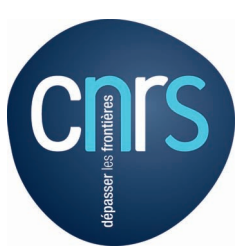

The publication of this article is financed by CNRS-INSU. 


\section{References}

Alcala, C. M. and Dessler, A. E.: Observations of deep convection in the tropics using the Tropical Rainfall Measuring Mission (TRMM) precipitation radar, J. Geophys. Res., 107, 4792, doi:10.1029/2002JD002457, 2002.

Alexander, M. J., Holton, J. R., and Durran, D. R.: The gravity wave response above deep convection in a squall line simulation, J. Atmos. Sci., 52, 2212-2226, 1995.

Alexander, S. P. and Tsuda, T.:, Observations of the diurnal tide during seven intensive radiosonde campaigns in Australia and Indonesia, J. Geophys. Res., 113, D04109, doi:10.1029/2007JD008717, 2008.

Anthes, R. A., Bernhardt, P. A., Chen, Y., Cucurull, L., Dymond, K. F., Ector, D., Healy, S. B., Ho, S.-P., Hunt, D. C., Kuo, Y.-H., Liu, H., Manning, K., McCormick, C., Meehan, T. K., Randel, W. J., Rocken, C., Schreiner, W. S., Sokolovskiy, S. V., Syndergaard, S., Thompson, D. C., Trenberth, K. E., Wee, T.-K., Yen, N. L., and Zeng, Z.: The COSMIC/FORMOSAT-3 Mission: Early Results, B. Am. Meteorol. Soc., 89, 313-333, doi:10.1175/BAMS89-3-313, 2008.

Biondi, R., Neubert, T., Syndergaard, S., and Nielsen, J. K.: Radio occultation bending angle anomalies during tropical cyclones, Atmos. Meas. Tech., 4, 1053-1060, doi:10.5194/amt-4-10532011, 2011.

Biondi, R., Randel, W. J., Ho, S.-P., Neubert, T., and Syndergaard, S.: Thermal structure of intense convective clouds derived from GPS radio occultations, Atmos. Chem. Phys., 12, 5309-5318, doi:10.5194/acp-12-5309-2012, 2012.

Burnham J.: Atmospheric gusts - a review of the results of some recent research at the royal aircraft establishment, Mon. Weather. Rev., 98, 723-734, 1970.

Cairo, F., Pommereau, J. P., Law, K. S., Schlager, H., Garnier, A., Fierli, F., Ern, M., Streibel, M., Arabas, S., Borrmann, S., Berthelier, J. J., Blom, C., Christensen, T., D’Amato, F., Di Donfrancesco, G., Deshler, T., Diedhiou, A., Durry, G., Engelsen, O., Goutail, F., Harris, N. R. P., Kerstel, E. R. T., Khaykin, S., Konopka, P., Kylling, A., Larsen, N., Lebel, T., Liu, X., MacKenzie, A. R., Nielsen, J., Oulanowski, A., Parker, D. J., Pelon, J., Polcher, J., Pyle, J. A., Ravegnani, F., Rivière, E. D., Robinson, A. D., Röckmann, T., Schiller, C., Simões, F., Stefanutti, L., Stroh, F., Some, L., Siegmund, P., Sitnikov, N., Vernier, J. P., Volk, C. M., Voigt, C., von Hobe, M., Viciani, S., and Yushkov, V.: An introduction to the SCOUT-AMMA stratospheric aircraft, balloons and sondes campaign in West Africa, August 2006: rationale and roadmap, Atmos. Chem. Phys., 10, 2237-2256, doi:10.5194/acp-10-2237-2010, 2010.

Chaboureau, J.-P., Cammas, J.-P., Duron, J., Mascart, P. J., Sitnikov, N. M., and Voessing, H.-J.: A numerical study of tropical crosstropopause transport by convective overshoots, Atmos. Chem. Phys., 7, 1731-1740, doi:10.5194/acp-7-1731-2007, 2007.

Chapman, S. and Lindzen, R. S.: Atmospheric Tides Thermal and Gravitational, D. Reidel, Dordrecht, Holland, 200 pp., 1970.

Chemel, C., Russo, M. R., Pyle, J. A., Sokhi, R. S., and Schiller, C.: Quantifying the imprint of a severe hector thunderstorm during ACTIVE/SCOUT-O3 onto the water content in the upper troposphere/lower stratosphere, Mon. Weather Rev., 137, 2493-2514, doi:10.1175/2008MWR2666.1, 2009.

Cornford, S. G. and Spavins, C. S.: Some measurements of cumulonimbus tops in the pre-monsoon season in North-East India,
Meteorological Magazine, 102, 314-332, 1973.

Corti, T., Luo, B. P., and Peter, T.: Mean radiative energy balance and vertical mass fluxes in the equatorial upper troposphere and lower stratosphere, Geophys. Res. Lett., 32, L06802, doi:10.1029/2004GL021889, 2005.

Corti, T., Luo, B. P., de Reus, M., Brunner, D., Cairo, F., Mahoney, M. J., Martucci, G., Matthey, R., Mitev, V., dos Santos, F. H., Schiller, C., Shur, G., Sitnikov, N. M., Spelten, N., Vossing, H. J., Borrmann, S., and Peter, T.: Unprecedented evidence for deep convection hydrating the tropical stratosphere, Geophys. Res. Lett., 35, L10810, doi:10.1029/2008GL033641, 2008.

Danielsen, E. F.: A dehydration mechanism for the stratosphere, Geophys. Res. Lett., 9, 605-608, 1982.

Danielsen, E. F.: In situ evidence of rapid, vertical, irreversible transport of lower tropospheric air into the lower stratosphere by convective cloud turrets and by large scale up welling in tropical cyclones, J. Geophys. Res, 98, 8665-8681, 1993.

de Reus, M., Borrmann, S., Bansemer, A., Heymsfield, A. J., Weigel, R., Schiller, C., Mitev, V., Frey, W., Kunkel, D., Kürten, A., Curtius, J., Sitnikov, N. M., Ulanovsky, A., and Ravegnani, F.: Evidence for ice particles in the tropical stratosphere from in-situ measurements, Atmos. Chem. Phys., 9, 6775-6792, doi:10.5194/acp-9-6775-2009, 2009.

Fueglistaler, S., Dessler, A. E, Dunkerton, T. J., Folkins, I., Fu, Q., and Mote, P. W.: The tropical tropopause layer, Rev. Geophys., 47, RG1004, doi:10.1029/2008RG000267, 2009.

Fujita, T. T.: Mystery of Severe Storms, during the 50 years 19421992, Wind Research Laboratory, Department of Geophysical Sciences, University of Chicago, 1992.

Gettelman, A. and Birner, T.: Insights into Tropical Tropopause Layer processes using global models, J. Geophys. Res., 112, D23104, doi:10.1029/2007JD008945, 2007.

Gettelman, A., Salby, M. L., and Sassi, F.: The distribution and in?uence of convection in the tropical tropopause region, J. Geophys. Res., 107, 4080, doi:10.1029/2001JD001048, 2002.

Gettelman, A., de F. Forster, P.M., Fujiwara, M., Fiu, Q., Vömel, H., Gohar, L. K., Johanson C., and Ammerman, M.: Radiation balance of the tropical layer, J. Geophys. Res., 109, D07103, doi:10.1029/2003JD004190, 2004.

Grosvenor, D. P., Choularton, T. W., Coe, H., and Held, G.: A study of the effect of overshooting deep convection on the water content of the TTL and lower stratosphere from Cloud Resolving Model simulations, Atmos. Chem. Phys., 7, 4977-5002, doi:10.5194/acp-7-4977-2007, 2007.

Hagan, M. E. and Forbes, J. M.: Migrating and non migrating diurnal tides in the middle and upper atmosphere excited by tropospheric latent heat release, J. Geophys. Res., 107, 4754, doi:10.1029/2001JD001236, 2002.

Harrison, E. F., Minnis, P., Barkstrom, B. R., Ramanathan, V., Cess, R. D., and Gibson, G. G.: Seasonal variation of cloud radiative forcing derived from the Earth Radiation Budget Experiment, J. Geophys. Res., 95, 18687-18703, 1990.

Holloway, C. E. and Neelin, J. D.: The convective cold top and quasi equilibrium, J. Atmos. Sci., 64, 1467-1487, 2007.

Iwasaki, S., Shibata, T., Nakamoto, J., Okamoto, H., Ishimoto, H., and Kubota, H.: Characteristics of deep convection measured by using the A-train constellation, J. Geophys. Res., 115, D06207, doi:10.1029/2009JD013000, 2010. 
Jensen, E. J., Ackerman, A. S., and Smith J. A.: Can overshooting convection dehydrate the tropical tropopause layer?, J. Geophys. Res., 112, D11209, doi:10.1029/2006JD007943, 2007.

Johnson, R. H. and Kriete, D. C.: Thermodynamic and circulation characteristics of winter monsoon tropical mesoscale convection, Mon. Weather Rev., 10, 1898-1911, 1982.

Khaykin, S., Pommereau, J.-P., Korshunov, L., Yushkov, V., Nielsen, J., Larsen, N., Christensen, T., Garnier, A., Lukyanov, A., and Williams, E.: Hydration of the lower stratosphere by ice crystal geysers over land convective systems, Atmos. Chem. Phys., 9, 2275-2287, doi:10.5194/acp-9-2275-2009, 2009.

Kiladis, G. N., Straub, K. H., and Haertel, P. T.: Zonal and vertical structure of the Madden-Julian oscillation, J. Atmos. Sci., 62, 2790-2809, 2005.

Kiladis, G. N., Wheeler, M. C., Haertel, P. T., Straub, K. H., and Roundy, P. E.: Convectively coupled equatorial waves, Rev. Geophys., 47, RG2003, doi:10.1029/2008RG000266, 2009.

Kuo, Y. H., Wee, T. K., Sokolovskiy, S., Rocken, C., Schreiner, W., Hunt, D., and Anthes, R. A.: Inversion and error estimation of GPS radio occultation data, J. Meteorol. Soc. Japan, 82(1B), 507-531, 2004.

Kursinski, E. R., Hajj, G. A., Schofield, J. T., Linfield, R. P., and Hardy, K. R.: Observing Earth's atmosphere with radio occultation measurements using the Global Positioning System, J. Geophys. Res., 102, 23429-23465, 1997.

Lane, T. P., Reeder, M. J., and Clark, T. L.: Numerical modeling of gravity wave generation by deep tropical convection, J. Atmos. Sci., 58, 1249-1321, 2001.

Lane, T. P., Sharman, R. D., Clark, T. L., and Hsu, H.-M.: An investigation of turbulence generation mechanisms above deep convection, J. Atmos. Sci., 60, 1297-1321, 2003.

Lieberman, R. S.: Non migrating diurnal tides in the equatorial middle atmosphere, J. Atmos. Sci., 48, 1112-1123, 2004

Liu, C. and Zipser, E. J.: Global distribution of convection penetrating the tropical tropopause, J. Geophys. Res., 110, D23104, doi:10.1029/2005JD006063, 2005.

Liu, X. M., Rivière, E. D., Marécal, V., Durry, G., Hamdouni, A., Arteta, J., and Khaykin, S.: Stratospheric water vapour budget and convection overshooting the tropopause: modelling study from SCOUT-AMMA, Atmos. Chem. Phys., 10, 8267-8286, doi:10.5194/acp-10-8267-2010, 2010.

McLandress, C.: The seasonal variation of the propagating diurnal tide in the mesosphere and lower thermosphere. Part II: The role of tidal heating and zonal mean winds, J. Atmos. Sci., 59, 907922, 2002.

Minnis, P. and Young, D. F.: Surface and clear-sky albedos and emissivities from MODIS and VIRS with application to SEVIRI, Extended abstract in proc. of the 2002 EUMETSAT Meteorological Satellite Conference Dublin, Ireland 2-6 September, 2002.

Nielsen, J. K., Larsen, N., Cairo, F., Di Donfrancesco, G., Rosen, J. M., Durry, G., Held, G., and Pommereau, J. P.: Solid particles in the tropical lowest stratosphere, Atmos. Chem. Phys., 7, 685695, doi:10.5194/acp-7-685-2007, 2007.

Norton, W. A.: Tropical Wave Driving of the Annual Cycle in Tropical Tropopause Temperatures. Part II: Model Results, J. Atmos. Sci., 63, 1420-1431, 2006.

Oberheide, J., Hagan, M. E., Roble, R. G., and Offermann, D.: Sources of nonmigrating tides in the tropical middle atmosphere, J. Geophys. Res., 107, 4567, doi:10.1029/2002JD002220, 2002.
Pirscher, B., Foelsche, U., Borsche, M., Kirchengast, G., and Kuo, Y.-H.: Analysis of migrating diurnal tides detected in FORMOSAT-3/COSMIC temperature data, J. Geophys. Res., 115, D14108, doi:10.1029/2009JD013008, 2010.

Pommereau, J.-P. and Held, G.: Is there a stratospheric fountain?, Atmos. Chem. Phys. Discuss., 7, 8933-8950, doi:10.5194/acpd7-8933-2007, 2007.

Randel, W. J. and Wu, F.: Thermal variability of the tropical tropopause region derived from GPS/MET observations, J. Geophys. Res., 108, 4024, doi:10.1029/2002JD002595, 2003.

Ricaud, P., Barret, B., Attié, J.-L., Motte, E., Le Flochmoën, E., Teyssèdre, H., Peuch, V.-H., Livesey, N., Lambert, A., and Pommereau, J.-P.: Impact of land convection on tropospherestratosphere exchange in the tropics, Atmos. Chem. Phys., 7, 5639-5657, doi:10.5194/acp-7-5639-2007, 2007.

Ricaud, P., Pommereau, J.-P., Attié, J.-L., Le Flochmoën, E., El Amraoui, L., Teyssèdre, H., Peuch, V.-H., Feng, W., and Chipperfield, M. P.: Equatorial transport as diagnosed from nitrous oxide variability, Atmos. Chem. Phys., 9, 8173-8188, doi:10.5194/acp9-8173-2009, 2009.

Roach, W. T and James, B. F.: A climatology of the potential vertical extent of giant cumulonimbus in some selected areas, Meteorological Magazine, 101, 161-181, 1972.

Rocken, C., Anthes, R., Exner, M., Hunt, D., Sokolovskiy, S., Ware, R., Gorbunov, M., Schreiner, W., Feng, D., Herman, B., Kuo, Y.-H., and Zou, X.: Analysis and validation of GPS/MET data in the neutral atmosphere, J. Geophys. Res., 102, 29849-29866, doi:10.1029/97JD02400, 1997.

Scherllin-Pirscher, B., Kirchengast, G., Steiner, A. K., Kuo, Y.H., and Foelsche, U.: Quantifying uncertainty in climatological fields from GPS radio occultation: an empirical-analytical error model, Atmos. Meas. Tech., 4, 2019-2034, doi:10.5194/amt-42019-2011, 2011a.

Scherllin-Pirscher, B., Steiner, A. K., Kirchengast, G., Kuo, Y.-H., and Foelsche, U.: Empirical analysis and modeling of errors of atmospheric profiles from GPS radio occultation, Atmos. Meas. Tech., 4, 1875-1890, doi:10.5194/amt-4-1875-2011, $2011 \mathrm{~b}$.

Schiller, C., Grooß, J.-U., Konopka, P., Plöger, F., Silva dos Santos, F. H., and Spelten, N.: Hydration and dehydration at the tropical tropopause, Atmos. Chem. Phys., 9, 9647-9660, doi:10.5194/acp-9-9647-2009, 2009

Schmetz J. and Liu, Q.: Outgoing long wave radiation and its diurnal variation at regional scales derived from Meteosat, J. Geophys. Res., 93, 11192-11204, 1988.

Schreiner, W., Rocken, C., Sokolovskiy, S., Syndergaard, S., and Hunt, D.: Estimates of the precision of GPS radio occultations from the COSMIC/FORMOSAT-3 mission, Geophys. Res. Lett., 34, L04808, doi:10.1029/2006GL027557, 2007.

Sherwood, S. C. and Dessler, A. E.: On the control of stratospheric humidity, Geophys. Res. Lett., 27, 2513-2516, 2000.

Sherwood, S. C. and Dessler, A. E.: Convective mixing near the tropical tropopause: Insights from seasonal variations, J. Atmos. Sci., 60, 2674-2685, 2003.

Sherwood, S. C., Horinouchi, T., and Zeleznik, H. A.: Convective impact on temperatures observed near the tropical tropopause, J. Atmos. Sci., 60, 1847-1856, 2003.

Smith, G. L. and Rutan, D. A.: The diurnal cycle of outgoing longwave radiation from Earth radiation budget experiment measurements, J. Atmos. Sci., 60, 1529-1542, doi:10.1175/2997.1, 2003. 
Steiner, A. K., Kirchengast, G., Lackner, B. C., Pirscher, B., Borsche, M., and Foelsche, U.: Atmospheric temperature change detection with GPS radio occultation 1995 to 2008, Geophys. Res. Lett., 36, L18702, doi:10.1029/2009GL039777, 2009.

Teitelbaum, H. and Vial, F.: On tidal variability by nonlinear interaction with planetary wave, J. Geophys. Res., 96, 14169-14178, 1991.

Tsuda, T., Murayama, Y., Wiryosumarto, H., Harijono, S. W. B., and Kato, S.: Radiosonde observations of equatorial atmosphere dynamics over Indonesia 1. Equatorial waves and diurnal tides, J. Geophys. Res., 99, 10491-10505, 1994.

Vernier, J. P., Pommereau, J. P., Garnier, A., Pelon, J., Larsen, N., Nielsen, J., Christensen, T., Cairo, F., Thomason, L. W., Leblanc, T., and McDermid, I. S.: The tropical stratospheric aerosol layer from CALIPSO lidar observations, J. Geophys. Res., 114, D00H10, doi:10.1029/2009JD011946, 2009.

Vernier, J.-P., Pommereau, J.-P., Thomason, L. W., Pelon, J., Garnier, A., Deshler, T., Jumelet, J., and Nielsen, J. K.: Overshooting of clean tropospheric air in the tropical lower stratosphere as seen by the CALIPSO lidar, Atmos. Chem. Phys., 11, 96839696, doi:10.5194/acp-11-9683-2011, 2011.

Vonnegut, B. and Moore, C. B.: Giant Electrical storms, Recent Advances in Atmospheric Electricity, Pergamon Press (London), 399-411, 1958.

Wang, P. K.: A cloud model interpretation of jumping cirrus above storm top, Geophys. Res. Lett., 31, L18106, doi:10.1029/2004GL020787, 2004.
Williams, C. R. and Avery, S. K.: Diurnal nonmigrating tidal oscillations forced by deep convective clouds, J. Geophys. Res., 101, 4079-4091, 1996.

Xie, F., Wu, D. L., Ao, C. O., and Mannucci, A. J.: Atmospheric diurnal variations observed with GPS radio occultation soundings, Atmos. Chem. Phys., 10, 6889-6899, doi:10.5194/acp-10-68892010, 2010.

Yang G.-Y. and Slingo J.: The diurnal cycle in the tropics, Mon. Weather Rev., 129, 784-801, 2001.

Zeng, Z., Randel, W., Sokolovskiy, S., Deser, C., Kuo, Y.-H., Hagan, M., Du, J., and Ward, W.: Detection of migrating diurnal tide in the tropical upper troposphere and lower stratosphere using the Challenging Minisatellite Payload radio occultation data, J. Geophys. Res., 113, D03102, doi:10.1029/2007JD008725, 2008.

Zeng, Z., Ho, S.-P., Sokolovskiy, S., and Kuo, Y.-H.: Structural evolution of the Madden-Julian Oscillation from COSMIC radio occultation data, J. Geophys. Res., 117, D22108, doi:10.1029/2012JD017685, 2012.

Zhang, X., Forbes, J. M., Hagan, M. E., Russell III, J. M., Palo, S. E., and Mlynczak, M.: Monthly tidal temperatures 20$120 \mathrm{~km}$ from TIMED/SABER, J. Geophys. Res., 111, A10S08, doi:10.1029/2005JA011504, 2006.

Zipser, E. J., Liu, C., Cecil, D.J., Nesbitt, S.W., and Yorty, D.P.: where are the most intense thunderstorms on Earth?, B. Am. Meteor. Soc., 87, 1057-1071, doi:10.1175/BAMS-87-8-1057, 2006. 